\title{
CHARACTERIZATION, QUANTIFICATION AND MANAGEMENT SITUATION OF MEDICAL WASTE IN NEPAL
}

\author{
Ahmad Kamruzzaman Majumder \\ Sanjay Nath Khanal \\ Gyanendra Chaudhary \\ Silu Bhochhibhoya \\ Sunita Kumari Yadav \\ Ashma Vaidya \\ Rabi Wenju \\ Kathmandu University, Kathmandu, Nepal
}

\begin{abstract}
Waste management is always a serious problem in developing country like Nepal. Medical waste has become a matter of major concern at present with the growth of health facilities in both public and private sectors of Nepal. It is a serious concern, as most of its waste goes to municipal waste management system. There is no proper or separate waste handling, dumping or incinerating practice for hazardous or hospital waste in Nepal. This study aimed to evaluate the characterization, quantification and management situation of various health care centers in Nepal. A study on the waste characterization and quantification as well as existing waste management system was conducted in six different hospitals and nursing homes of Nepal during 2004 to 2007 . These hospitals has been serving about 0.25 million patients in average every year. The methodology involved in the study is the collection of the waste from each ward, segregation, characterization into infectious, non-infectious waste groups and quantification. In each hospital investigation was conducted for 7-15 days. Existing management practice were directly observed and documented. Necessary information was also collected through formal and informal consultations with different stakeholders of the concern hospitals. This study found that the average daily waste generation in surveyed hospitals is $69.35 \mathrm{~kg}$. The average per capita waste generation in these hospitals is $0.66 \mathrm{~kg}$ in which infectious waste was $0.13 \mathrm{~kg} /$ day/person and non-infectious waste was 0.53 $\mathrm{kg} /$ day/person. The average infectious waste was almost $22.07 \%$ and non- infectious waste was $77.93 \%$ in the surveyed hospitals. Application of strong policies and legislation measures for proper management of the medical waste is highly needed.
\end{abstract}

\section{KEYWORDS}

Medical waste; Hazardous waste; Non-hazardous waste; Infectious waste; Nepal.

\section{INTRODUCTION}

Waste management is always a serious problem in developing country like Nepal. Medical waste has become a matter of major concern at present with the growth of health facilities in 
both public and private sectors of Nepal. It is a serious concern, as most of its waste goes to municipal waste management system. There is no proper or separate waste handling, dumping or incinerating practice for hazardous or hospital waste in Nepal. The per capita waste generation in urban Nepal varies from 0.25 to $0.5 \mathrm{~kg} /$ person/day depending upon the size of municipalities [1]. In a recent survey conducted by ENPHO on hospital waste management, it was estimated that Kathmandu city alone generates about one ton of hazardous hospital waste per day. Few of the individual healthcare institutions have set treatment facilities such as waste incinerators and autoclave to treat its waste. However, establishment of such treatment systems are not very common in Nepal. So far, there are no municipalities in the country having the provision of waste incineration facilities to treat municipal waste. There is no separate management of special healthcare waste within the healthcare establishments. Most of the time, all healthcare wastes are mixed together. As a result, the general waste is also contaminated with infectious and hazardous waste. Finally, they dispose their untreated waste into the municipal container. Likewise, as there is no regulations for particular hazardous materials such as mercury, and other heavy metals, chlorinated compounds etc, there are no particular benefits for the healthcare facilities to avoid these substances, and thereby to save the environment and the public health for these materials (Kafle, 2003). At the municipal level, healthcare waste rarely receives special attention; rather, it is handled as part of the municipal waste stream. As a consequence, the total quantity of the municipal waste (around $200 \mathrm{MT} /$ day) becomes contaminated with infectious and hazardous waste (K.C., 2004). There seems not to be many initiations to minimize quantities of waste or substitution of hazardous materials at the healthcare facilities. Only in few cases, a proper waste segregation takes place, which leads to less quantities of healthcare risk waste [2]. Likewise, there is hardly any awareness of green procurement. At some healthcare facilities, needles for certain kinds of inoculation and gloves are recycled by steam (Kafle, 2003). In the valley, huge part of the total bio-healthcare waste generated is treated while the rest is dumped in the dumping grounds along with the domestic waste [3]. A number of surveys have been conducted in the Kathmandu valley to establish an overview of the healthcare waste management. Two of them include surveys of the quantities of Health Care Waste (HCW) and Health Care Risk Waste (HCRW). The first survey was conducted in 1997 and included measurements of the quantities of waste generated at 11 hospitals in the Kathmandu Valley. The average quantity of waste estimated for all $11 \mathrm{HCFs}$ appear the HCW is $0.54 \mathrm{~kg} /$ patient/day and HCRW is 0.16 $\mathrm{kg} /$ patient/day. Another survey conducted in 2001 by the Environment \& Public Health Organization (ENPHO) for the Kathmandu Valley Mapping Programme, Kathmandu Metropolitan City, shows somewhat higher figures, HCW is $1.7 \mathrm{~kg} /$ patient/day and HCRW is $0.48 \mathrm{~kg} /$ patient/day. A report on medical waste management in developing countries, WHO, Geneva, 1994, states that the hospital waste is consist of $85 \%$ general waste (non-hazardous), $5 \%$ are infectious and $10 \%$ are non-infectious but hazardous. It has been estimated that out of total medical waste produced; only $10-20 \%$ waste produced is hazardous in nature [4].

This study aimed to evaluate the characterization, quantification and management situation of various healthcare centers in Nepal. ICDDR, B (2001) classification of medical wastes as Infectious wastes, Pathological wastes, Sharp wastes, Chemical wastes, Pharmaceutical wastes, radioactive wastes, Wastes with high content of heavy metals, Pressurized containers. [5], classified medical wastes in four different categories based on their sources and potential

hazards they may cause. Those are kitchen waste, non-clinical waste, laboratory waste, and clinical waste. The most vulnerable group prone to accidents, injuries and infection from hazardous medical wastes is people who are in direct contact with this type of waste like 
nurses, waste handlers, scavengers etc. Infectious waste may contain number of pathogens and these pathogens can enter into the body through various routes like puncture, abrasion, or cut in the skin, by inhalation or through the mucous membranes. Patient and visitors attending these establishment are also equally at risk [6].

\section{MATERIALS AND METHODS}

\subsection{Study area}

The study on the waste characterization and quantification as well as existing waste management system was conducted in six different hospitals and Nursing homes of Nepal during 2004 to 2007 (Figure 1). This health centers includes a government Narayani Hospital, Birgunj, B\&B Hospital, Kathmandu, Private Shah Nursing Home, Birgunj, Private Shiva Hospital, Birgunj, registered missionary Scheer Memorial Hospital, Banepa and Community conceived and community supported health service center Dhulikhel Hospital. These hospitals has been serving about 0.25 million patients in average every year. Out of six hospitals Dhulikhel Hospital and Scheer Memorial Hospital is the teaching hospital of Kathmandu University.

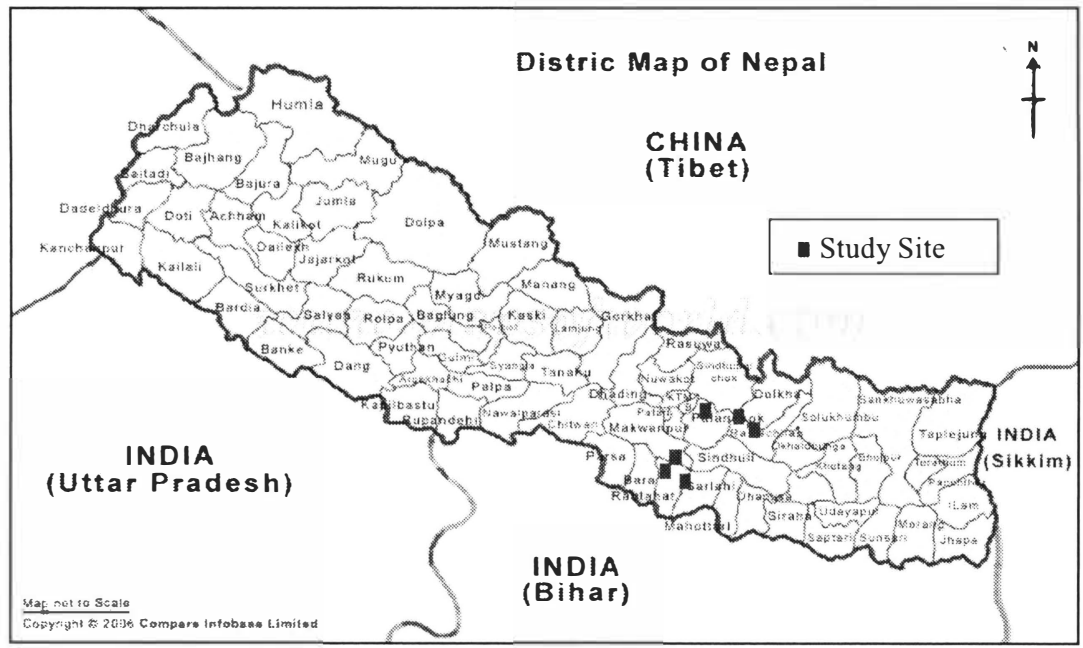

Figure 1. Map showing the study area.

\subsection{Methodology}

This study is based on both primary and secondary data. The methodology involved in this study is the collection of the waste from each ward, segregation, characterization into infectious, non-infectious waste groups and quantification. In each hospital investigation was conducted for 7-15 days. Existing management practice were directly observed and documented. Necessary information was also collected through formal and informal consultations with different stakeholders of the concern hospitals. Primary data was collected 
from the field survey at different wards of selected hospitals, stores places inside hospital and final disposal area inside hospital and undefined dumping site of waste authority. A surface study of the waste management system of the hospital was done to make outline the statement of problem for the study. Various information required for the study was retrieved through the administration of the questionnaires to the relevant authorities including the director, doctors, nurses, ward boys, executive officer, the supervisor of the housekeeping department, peoples around the hospitals and the workers involved in the waste handling activities.

For the qualitative analysis, the waste generation points at various wards in the hospital were located and waste collection team were informed about the research study being carried out. The collection of the waste was done every day for seven to fifteen consecutive days to obtain the representative data. The collected waste from each wards were brought to the place nearby the area or room for storage and the waste from different wards were segregated separately, and characterized into sharps, hazardous and non-hazardous waste groups. The safety measures as gloves and masks were put on properly before the sorting was done to avoid any kind of accidents or injuries. After the characterization, each waste type and the items were weighed separately, and the weights obtained were noted down for the data processing, analysis and interpretations. The weighing was done by a spring balance of capacity $20 \mathrm{~kg}$. At times, when certain item weighs more than $20 \mathrm{~kg}$, they were divided into fractions, and weighed. Different items were weighed separately as far as possible, and later on during the data processing, the items were classified into three basic groups as per NHRC classification of Healthcare waste. All the data collected by the field survey were analyzed with the help of computer software, calculator conversion, MS-Word, MS-Excel for graphical analysis and presentation.

\section{RESULTS AND DISCUSSION}

\subsection{Total waste generation and its quantification}

A clear scenario of medical waste generation, their category and present management system of some government and non-government hospitals in Nepal were produced by this study. Table 1 shows that the average capacity of the hospital is 112 which range 25 to 200 .

Table 1. General information about selected surveyed hospitals in Nepal.

\begin{tabular}{|c|c|c|c|c|}
\hline Name of the hospital & Type & Location & Capacity & Average patient \\
\hline B\&B Hospital & Private & Kathmandu & 150 & 150 \\
\hline Dhulikhel Hospital & Community \& Teaching & Dhulikhel & 120 & 120 \\
\hline Scheer Memorial Hospital & Missionary \& Teaching & Banepa & 150 & 130 \\
\hline Narayani Hospital & Government & Birgunj & 200 & 202 \\
\hline Shah Nursing Home & Private & Birgunj & 25 & 20 \\
\hline Shiva Hospital & Private & Birgunj & 30 & 21 \\
\hline & Average & & 112 & 107 \\
\hline
\end{tabular}


Table 2. Waste generation in surveyed hospitals in Nepal.

\begin{tabular}{lccc}
\hline \multicolumn{1}{c}{ Name of the hospital } & $\begin{array}{c}\text { Average number of } \\
\text { Patient }\end{array}$ & $\begin{array}{c}\text { Total daily waste } \\
\text { generation }(\mathrm{kg})\end{array}$ & $\begin{array}{c}\text { Total waste } \\
\text { generation } \\
(\mathrm{kg} / \text { day/person })\end{array}$ \\
\hline B\&B Hospital & 150 & 74.8 & 0.5 \\
\hline Dhulikhel Hospital & 120 & 39.74 & 0.33 \\
\hline Scheer Memorial Hospital & 130 & 33.11 & 0.26 \\
\hline Narayani Hospital & 202 & 232.12 & 1.14 \\
\hline Shah Nursing Home & 20 & 18.41 & 0.92 \\
\hline Shiva Hospital & 21 & 17.9 & 0.85 \\
\hline Total Average & 107 & 69.35 & 0.66 \\
\hline
\end{tabular}

Table 2 shows that the average number of patient in the surveyed hospital is 107 and the average quantity of waste generated from surveyed hospital is $69.35 \mathrm{~kg}$. Daily average waste generation is $69.35 \mathrm{~kg}$ and daily average per person waste generation is $0.66 \mathrm{~kg}$ which is much lower than that of $4.5 \mathrm{~kg}$ in USA, $2.7 \mathrm{~kg}$ in Netherlands and $2.5 \mathrm{~kg}$ in France. However, the average hospital waste generations rates are in the range of $1-4.5 \mathrm{~kg} / \mathrm{bed} / \mathrm{day}$ in Latin America countries like Chile, Brazil, Argentina, Venezuela [7].

\subsection{Categorization waste from selected surveyed hospitals in Nepal}

Table 3 reveals that more than $77 \%$ waste is non-infectious and only less than $23 \%$ of waste is infectious in selected surveyed hospitals in Nepal. [8] reported that $85 \%$ of hospital waste in Asia are non-infectious. From the present study it is found that the amount of infectious waste is higher in Dhulikhel Hospital where it is found about $37.27 \%$ of the total waste. B\&B Hospital and Scheer Memorial Hospital also generate more then $20 \%$ of the infectious waste. In Narayani Hospital, Shah Nursing Home and Shiva Hospital the generation of infectious waste is lower which is $17.01 \%, 15.10 \%$ and $14.47 \%$ of the total waste, respectively.

The percentages of infectious waste in Nepal is higher than that of Netherlands (5\%) and Sweden $(8 \%)$, and lower than that of Denmark $(25 \%)$ and USA $(28 \%)$, and is near about close to the rate generated in Germany (14\%). This indicated difference may be due to geographical location, living habits and standards, availability of different treatment facilities, and perhaps to the way in which solid waste are categorized in different countries [7].

Table 3. Categorization of the waste in selected surveyed hospitals in Nepal.

\begin{tabular}{lccccc}
\hline $\begin{array}{c}\text { Name of the } \\
\text { hospital }\end{array}$ & $\begin{array}{c}\text { Total daily } \\
\text { generation }(\mathrm{kg})\end{array}$ & Infectious & $\begin{array}{c}\text { Non } \\
\text { Infectious }\end{array}$ & $\begin{array}{c}\% \text { of } \\
\text { Infectious }\end{array}$ & $\begin{array}{c}\% \text { Non } \\
\text { Infectious }\end{array}$ \\
\hline B\&B Hospital & 74.8 & 17.78 & 57.02 & 23.77 & 73.27 \\
\hline Dhulikhel Hospital & 39.74 & 14.81 & 24.93 & 37.27 & 62.73 \\
\hline $\begin{array}{l}\text { Scheer Memorial } \\
\text { Hospital }\end{array}$ & 33.11 & 8.2 & 24.91 & 24.77 & 75.23 \\
\hline Narayani Hospital & 232.12 & 39.48 & 192.64 & 17.01 & 82.99 \\
\hline Shah Nursing Home & 18.41 & 2.78 & 15.63 & 15.10 & 84.90 \\
\hline Shiva Hospital & 17.9 & 2.59 & 15.31 & 14.47 & 85.53 \\
\hline Total Average & 69.35 & 14.27 & 55.07 & 22.07 & 77.93 \\
\hline
\end{tabular}


Table 4. Quantification of infectious and non-infectious waste in selected surveyed hospitals in Nepal.

\begin{tabular}{|c|c|c|c|c|c|c|}
\hline \multirow{2}{*}{$\begin{array}{c}\text { Name of the } \\
\text { hospital }\end{array}$} & \multirow{2}{*}{$\begin{array}{c}\text { Total daily } \\
(\mathrm{kg})\end{array}$} & \multirow{2}{*}{$\begin{array}{c}\text { Average } \\
\text { patient }\end{array}$} & \multicolumn{2}{|c|}{ Infectious } & \multicolumn{2}{|c|}{ Non-infectious } \\
\hline & & & Total & Day/person & Total & Day/person \\
\hline B\&B Hospital & 74.8 & 150 & 17.78 & 0.12 & 57.02 & 0.38 \\
\hline Dhulikhel Hospital & 39.74 & 120 & 14.81 & 0.12 & 24.93 & 0.21 \\
\hline Scheer Memorial & & & & & & \\
\hline Hospital & 33.11 & 130 & 8.2 & 0.07 & 24.91 & 0.19 \\
\hline Narayani Hospital & 232.12 & 202 & 39.48 & 0.20 & 192.64 & 0.95 \\
\hline Shah Nursing & & & & & & \\
\hline Home & 18.41 & 20 & 2.78 & 0.14 & 15.63 & 0.78 \\
\hline Shiva Hospital & 17.9 & 21 & 2.59 & 0.12 & 15.31 & 0.73 \\
\hline Total Average & 69.35 & 107.17 & 14.27 & 0.13 & 55.07 & 0.52 \\
\hline
\end{tabular}

Table 4 shows the generation rate of infectious and non-infectious waste were 0.13 $\mathrm{kg} /$ day/person and $0.52 \mathrm{~kg} /$ day/person, respectively and the total waste generation is about $0.65 \mathrm{~kg} /$ day $/$ person.

Table 5. Yearly waste generation in surveyed three hospitals by weight $(\mathrm{kg})$ and types.

\begin{tabular}{|c|c|c|}
\hline Name of the hospital & $\begin{array}{c}\text { Total daily hospital waste } \\
\text { generation }(\mathrm{kg})\end{array}$ & $\begin{array}{c}\text { Projected yearly } \\
\text { generation }(\mathrm{kg})\end{array}$ \\
\hline B\&B Hospital & 74.80 & $27,302.00$ \\
\hline Dhulikhel Hospital & 39.74 & $14,505.10$ \\
\hline Scheer Memorial Hospital & 33.11 & $12,085.15$ \\
\hline Narayani Hospital & 232.12 & $84,723.80$ \\
\hline Shah Nursing Home & 18.41 & $6,719.65$ \\
\hline Shiva Hospital & 17.90 & $6,533.50$ \\
\hline Total Average & 69.35 & $151,869.20$ \\
\hline
\end{tabular}

Table 5 shows the projected yearly generation of total waste in selected six hospitals is $151,869 \mathrm{~kg}$. This increasing amount of waste, if not managed properly will cause severe health and environmental problems. Though, the non-hazardous or non-infectious waste can be dumped in open place with other waste but the hazardous and infectious waste needs special treatment before dumping so that it cannot spread germs.

\subsection{Existing management practice}

Table 6 shows the existing waste management practice in selected surveyed hospitals in Nepal. It is observed that existing hospital waste collection, handling and disposal practices of all the hospitals involved transport of wastes by ward boys, maid nurses and other employees from the point of generation to initial storage points in each unit. Hospital waste is seen to be dumped at various corner of the hospital owns boundary. Waste normally collected from small bowl or plastic bin, provided for each bed in a hospital or clinics and put them either in a large bucket. These wastes from buckets are then put in a pushcart or directly carried to the nearest municipal bins for dumping. The municipal bins are normally placed either in hospital premises or outside the hospital. In most cases waste from Operation Theater, laboratory and 
hospital kitchen are also dumped into municipal bins. Municipality's trucks carry them to the landfill area for the final dumping.

Table 6. Existing waste management practice in selected surveyed hospitals in Nepal.

\begin{tabular}{|c|c|c|c|c|c|}
\hline $\begin{array}{l}\text { Name of } \\
\text { hospital }\end{array}$ & $\begin{array}{l}\text { Segregation } \\
\text { Practice }\end{array}$ & $\begin{array}{l}\text { Separate buckets } \\
\text { for different } \\
\text { categories of } \\
\text { waste }\end{array}$ & $\begin{array}{l}\text { Covered } \\
\text { buckets }\end{array}$ & Incineration & Transfer to the disposal sites. \\
\hline$B \& B$ & Satisfactory & 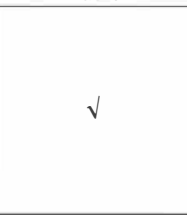 & $\mathrm{x}$ & $\sqrt{ }$ & $\begin{array}{l}\text { Both the infectious and non- } \\
\text { infectious waste are separated in } \\
\text { different buckets and infectious } \\
\text { waste is taken into incinerator } \\
\text { whereas general waste are carried } \\
\text { to the disposal site where it is taken } \\
\text { by municipalities }\end{array}$ \\
\hline Dhulikhel & Moderate & $\sqrt{ }$ & $\sqrt{ }$ & $\sqrt{ }$ & $\begin{array}{l}\text { General waste and infectious are } \\
\text { carried in the same wheeled cat and } \\
\text { disposed together. All the collected } \\
\text { wastes are disposed into incinerator } \\
\text { which is simply firing. }\end{array}$ \\
\hline $\begin{array}{l}\text { Scheer } \\
\text { Memorial } \\
\text { Hospital }\end{array}$ & Satisfactory & $\sqrt{ }$ & $\sqrt{ }$ & $\sqrt{ }$ & $\begin{array}{l}\text { Both the infectious and non- } \\
\text { infectious waste is separated in } \\
\text { different buckets and infectious } \\
\text { waste is taken into incinerator. } \\
\text { General waste are carried to the } \\
\text { disposal site where it is taken by } \\
\text { municipalities }\end{array}$ \\
\hline $\begin{array}{l}\text { Narayani } \\
\text { Hospital }\end{array}$ & Poor & $\mathrm{x}$ & $\mathrm{x}$ & $\mathrm{x}$ & $\begin{array}{l}\text { Carried to the disposal site with out } \\
\text { Segregation where it is taken by } \\
\text { municipalities for open dumping }\end{array}$ \\
\hline $\begin{array}{l}\text { Shah Nursing } \\
\text { Home }\end{array}$ & Poor & $\mathrm{x}$ & $x$ & $\mathrm{x}$ & Dumping to the municipal dumpsite \\
\hline $\begin{array}{l}\text { Shiva } \\
\text { Hospital }\end{array}$ & Poor & $\mathrm{x}$ & $\mathrm{X}$ & $\mathrm{x}$ & Dumping to the municipal dumpsite \\
\hline
\end{tabular}

\section{CONCLUSIONS}

This study concludes that the average daily waste generation in surveyed hospitals is 69.35 $\mathrm{kg}$. The average per capita waste generation in these hospitals is $0.66 \mathrm{~kg}$ in which infectious waste was $0.13 \mathrm{~kg} /$ day/person and non-infectious waste was $0.53 \mathrm{~kg} /$ day $/$ person. The average infectious waste was almost $22.07 \%$ and non-infectious waste was $77.93 \%$ in the surveyed hospitals. Treated as medical waste as municipal waste in Nepal is one of major mistake in the hygienic point of view. Thus, only little proportion infectious and hazardous wastes from hospitals require special attention for their proper disposal. The remaining portion of waste can be disposed off into the municipal dustbins. This small portion of hazardous waste also mixed with general waste and disposed in municipal bin without any treatment and which is finally taken by municipality truck along with municipal waste, which makes the whole body of municipal waste as infectious. This is one of the parts of environmental hazard at present as well as in future. Out of six hospitals only three have incinerator but one is not working now. Application of strong policies and legislation measures related to the medical waste management for proper management of the medical waste is highly needed. 


\section{RECOMMENDATIONS}

- Application of strong policies and legislation measures related to the medical waste management for proper management of the medical waste is highly needed.

- There should be a treatment facility in the city for medical waste. There must be accountability of the concerned authority. Incineration is a good method to destroy medical waste, but in recent it had gained bad reputation for its air pollution by dioxin, furan and heavy metal ash. There are other alternative methods like: chemical treatment, Microwave Technology, Bio-oxidation, Autoclaving etc.

- However incinerator is considered as a best solution for safe disposal of medical waste since the amount hazardous waste is found very little in compare with other nonhazardous waste in case of hospital waste in Nepal. There is bio-oxidation process also, which is better, Microwave system may be used.

- This study also suggested making awareness among healthcare staffs and waste handlers about the varieties of waste categories and their potential impacts so as to prepare a desirable way in managing medical waste.

- Intervention is required at all the stages of waste management- form the formulation of appropriate laws, segregation of waste, transportation of waste to the final disposal method. Among different treatment options, incinerator has been found as the most suitable one for city as it has capacity to burn the hazardous waste completely. All Health Care Institutions should be committed to waste management from generation to final disposal.

- Every hospital and clinics must allot budget for medical waste disposal companies.

- The establishment of a waste management committee and the development of waste management plan are required.

\section{ACKNOWLEDGEMENT}

The authors are thankful to the Department of Environmental Science and Engineering and the administration of Kathmandu University for their support to carry out this study.

\section{REFERENCES}

[1] Nepal Bureau of Statistics. 2001. Population Census and Urban Aral 2001. Ministry of Population and Environment

[2] Majumder, A. K., Chaudhary,G., Datta, D.K., 2007. Medical Waste Management Situation And Potential Option For Management; A Case Study In Birgunj City, Nepal, Paper presented National Conference on Environment organized by Central Department of Environmental Science, Tribhuvan University in 22, 23 and 24 June 2007 in Kathmandu, Nepal

[3] ENPHO, 2001 A report on Medical Waste Management in Kathmandu Valley, Nepal

[4] Pruss, A., E. Giroult., P. Rushbook,. 1999. Safe Management of waste from Health care activities, WHO, Geneva.

[5] Akter, N., 2002. Scenario of Hospital Waste management in Bangladesh. Bangladesh Environment 2002. ed. By M. Foroz Ahmed, Saleh A. Tanveeer, and A.B.M Badruzzaman. Dhaka: Bangladesh Poribesh Andolon (BAPA).

[6] Rawal Birendra, 2004. Medical waste management in Kathmandu Valley, Kathmandu, Nepal 
[7] Monreal, J., 1991. Consideration on the management of Hospital Wastes in Latin America, Geneva: Environmental Health Program, PAHO / WHO.

[8] WHO., 1994a. Guidelines for safe disposal of unwanted pharmaceuticals in and after emergencies, Geneva: Essential drugs and Other Medicines Department, World Health Organization.

[9] WHO., 1994b. "Managing clinical wastes in Developing Countries" Report of a Consultation on Clinical Waste Management in Developing Countries. September 1992. ed. By Dr. Coad, A. Geneva: World Health Organization.

[10] BAN \& HCWH. 1999. Medical Waste in Developing Countries, An analysis with a case study of India, and a critique on the Basel- TWG guidelines. Seattle: Basel Action Network Secretariat.

[11] Katmandu Declaration on Medical Waste Management (English version) http://www.nepalnews.com / Kantipur daily news.

[12] Khandker, F. 1999. Clinical Waste Management in Khulna City. URP Dissertation Nepal Health Research Council, (2002) National Health Care Waste Management Guidelines, Kathmandu, Nepal

[13] M. Habibur Rahman, S. Noor-UD-Deen, Ahmed M. Shebab Ullah., 1999. A study on hospital waste management in Bangladesh. 25th WEDC Conference, Dhaka, Bangladesh

[14] Turnberg, W.L., 1996. Bio Hazardous Waste, Risk Assessment, Policy and Management. USA: John Wiley snd Sons Inc. 